\section{OPEN ACCESS}

Approved by:

Frontiers Editorial Office,

Frontiers Media SA, Switzerland

*Correspondence:

Flavia Ismael

flaviaism@yahoo.com.br

Specialty section: This article was submitted to

Public Mental Health

a section of the journal

Frontiers in Public Health

Received: 30 April 2021

Accepted: 19 May 2021

Published: 16 June 2021

Citation

Ismael $F$, Zaramella B, Battagin $T$,

Bizario JCS, Gallego J, Villela V,

de Queiroz LB, Leal FE, Torales J,

Ventriglio A, Marziali ME,

Gonçalves PD, Martins SS and

Castaldelli-Maia JM (2021)

Corrigendum: Substance Use in Mild-COVID-19 Patients: A

Retrospective Study.

Front. Public Health 9:703562.

doi: 10.3389/fpubh.2021.703562

\title{
Corrigendum: Substance Use in Mild-COVID-19 Patients: A Retrospective Study
}

\begin{abstract}
Flavia Ismael ${ }^{1,2 *}$, Beatriz Zaramella ${ }^{1}$, Tatiane Battagin ${ }^{1}$, João C. S. Bizario ${ }^{3}$, Júlia Gallego ${ }^{1}$, Victoria Villela' ${ }^{1}$, Lilian Bezerra de Queiroz ${ }^{1}$, Fabio E. Leal ${ }^{1}$, Julio Torales ${ }^{4}$, Antonio Ventriglio ${ }^{5}$, Megan E. Marziali ${ }^{6}$, Priscila D. Gonçalves ${ }^{6}$, Silvia S. Martins ${ }^{6}$ and João M. Castaldelli-Maia ${ }^{6}$

${ }^{1}$ Universidade Municipal de São Caetano do Sul, São Caetano do Sul, Brazil, ${ }^{2}$ ABC Center for Mental Health Studies, Santo André, Brazil, ${ }^{3}$ Faculdade de Medicina de Olinda, Olinda, Brazil, ${ }^{4}$ Department of Psychiatry, School of Medical Sciences, National University of Asunción, Asunción, Paraguay, ${ }^{5}$ Department of Clinical and Experimental Medicine, University of Foggia, Foggia, Italy, ${ }^{6}$ Department of Epidemiology, Mailman School of Public Health, Columbia University, New York, NY, United States
\end{abstract}

Keywords: COVID-19, alcohol, analgesics, cannabis, tobacco, benzodaizepine

\section{A Corrigendum on}

Substance Use in Mild-COVID-19 Patients: A Retrospective Study by Ismael, F., Zaramella, B., Battagin, T., Bizario, J. C. S., Gallego, J., Villela, V., et al. (2021). Front. Public Health 9:634396. doi: 10.3389/fpubh.2021.634396

In the original article, we neglected to include the funder "NIDA", "T32DA031099 (Hasin)" to "Priscila D. Gonçalves".

The authors apologize for this error and state that this does not change the scientific conclusions of the article in any way. The original article has been updated.

Copyright (๑) 2021 Ismael, Zaramella, Battagin, Bizario, Gallego, Villela, de Queiroz, Leal, Torales, Ventriglio, Marziali, Gonçalves, Martins and Castaldelli-Maia. This is an open-access article distributed under the terms of the Creative Commons Attribution License (CC BY). The use, distribution or reproduction in other forums is permitted, provided the original author(s) and the copyright owner(s) are credited and that the original publication in this journal is cited, in accordance with accepted academic practice. No use, distribution or reproduction is permitted which does not comply with these terms. 